\title{
The Concept of Gender in the Czech Rural History and Historiography
}

\section{MARKÉTA SKOŘEPOVÁ}

The opening of state frontiers after 1989 brought a considerable widening of horizons to the Czech historiography. Among the research trends which experienced the fastest upswing were also gender studies, although they were particularly oriented on women's history. Monographs dedicated to the $19^{\text {th }}$ century women, which were published at the turn of the millennia, were targeted at a wider spectrum of readers and they won a strong response from outside the narrow community of experts. ${ }^{1}$ The interest in cultural history of women and the development of women's movement were supported by the first published Czech translations. ${ }^{2}$

The demand for these topics was reflected in the offer of public lectures, ${ }^{3}$ publishing of new professional and popularising books, and in the amount of student theses dedicated to various aspects of women's history in the past. The period of feverish research into women's history culminated at the end of the first decade of the $21^{\text {st }}$ century with publication of a representative collective monograph about women in the Czech lands from the Middle Ages until the $20^{\text {th }}$ century. ${ }^{4}$ The French concept of the cultural history of women, ${ }^{5}$ which was introduced into the Czech milieu by Milena Lenderová in the 1990s, already partly cleared the way for a more modern concept of gender history, and the chronological interpretation was replaced by thematic complexes. The incoming

A bestseller, honoured with many reader's and literary awards, was the work by Milena Lenderové, K hríchu i k modlitbě. Žena v minulém století, Praha 1999. The book by Pavla Horská, Naše prababičky feministky, Praha 1999, also has significant popularising qualities.

2 Edith Ennenová, Ženy ve středověku, Praha 2001 (Edith Ennen, Frauen im Mittelalter, München 1984); Lynn Aв ramsová, Zrozeni moderní ženy. Evropa 1784-1915, Praha 2005 (Lynn Aвrams, The making of modern woman. Europe 1789-1918, New York 2002); Gisela Bocкоvá, Ženy v evropských déjinách: od středovéku do současnosti, Praha 2007 (Gisela Bоск, Frauen in der europäischen Geschichte. Vom Mittelalter bis zur Gegenwart, München 2000).

3 Some of them were published later as a book Milena Lenderová (ed.), Eva nejen v ráji. Žena v $\check{C}_{e-}$ chách od stredovéku do 19. století, Praha 2002.

4 Milena Lenderová - Božena KopičKová - Jana Burešová - Eduard Maur (edd.), Žena v českých zemich od stredověku do 20. století, Praha 2010.

5 Georges Duby - Michelle Perrot, Histoire des Femmes I-V, Paris 1987-1992. 
trend of examining the femininity and masculinity, ${ }^{6}$ the ways of their construction and mutual interactions, brought the $\mathrm{Czech}$ gender studies back to academic study rooms and conference sessions, although the demand of readers for the "classical“ history of women and men apparently remains considerably high. ${ }^{7}$

Despite the above-mentioned popularity and despite the fact that gender history currently represents a standard part of curricula of the educational programmes for future historians, many little-explored topics still remain. One of them is the reflection of gender in the rural space from the Middle Ages to this day, although a relatively high number of researchers were, or still are, occupied with agrarian history or with Czech historical ethnology.

The rural history, which systematically developed since the second half of the $19^{\text {th }}$ century, reached the first imaginary peak at the time of positivistic historiography during the First Czechoslovak Republic (1918-1938), when this topic was treated by the most prominent figures in the then historiographic science, such as Josef Pekar $\check{r}^{8}$ or the ethnographer Čeněk Zíbrt. ${ }^{9}$ The second boom of research interest began in the 1960s in connection with Marxism, which was influenced by the study of economic history. After 1989, however, historians turned the most part of their attention to topics which were neglected until that time. The rural history thus stood a little apart. An example might be the history of women or, more generally, gender history, which developed very fast on the basis of sources from aristocratic or „bourgeois“ circles and the previously favoured „working classes“, including the villagers, were sidelined.

In the positivistic works inspired by Marxism, rural population was presented as a nameless and neutral „Czech folk“ or „subjects“, ${ }^{10}$ whose identity or diversity were determined nationally (Czech vs. foreign/German population), socially (farmers vs. lacklands, sometimes with reference to class struggle), and in exceptional cases also religiously (Catholicism vs. Reformation). ${ }^{11}$ In the mass of rural subjects we can sometimes

6 The first complex contribution to the study of the history of masculinity is a collective monograph by Radmila Švaříč́ová Slabáková - Jitka Kohoutová - Radmila Pavlíč́ová - Jiří HutečKa et alii., Konstrukce maskulinní identity v minulosti a současnosti. Koncepty, metody, perspektivy, Praha 2012. However, this work did not treat the topic of social issues in rural space.

7 This is also attested by a second edition of the work by M. Lenderová with slightly modified subtitle, Milena Lenderové, K hř́chu i k modlitbè. Žena devatenáctého století, Praha 2016.

$8 \quad$ Particularly Josef Peкař, Kniha o Kosti. Kus české historie I-II, Praha 1910-1911.

9 As a representative example we can name Čeněk Zíbrt, Veselé chvíle v životě lidu českého, Praha 1910-1911.

10 Kamil Krofta, Déjiny selského stavu, Praha 1949.

11 Selectively František Graus, Dějiny venkovského lidu v Čechách v době predhusitské I. Dẽjiny venkovskébo lidu od 10. stoleti do proni poloviny 13. století, Praha 1953; Alois MíkA, Poddaný lid v Čechách v proní polovině 16. století, Praha 1960; Josef Petráñ, Poddaný lid v Čechách na prahu tricetileté války, Praha 1964. 
recognize real people, respectively men, playing the role of folk leaders - either manorial reeves or rebels. ${ }^{12}$ The texts which are inspired by historical anthropology or are searching for historical discourses did not change their original asexual or indifferently masculine portrayals of rural people. ${ }^{13}$

The first, and to this day virtually the only, research area, which was able to study men and women in the historical rural space in both their physical nature and their gender role, was historical demography. This discipline has developed in Czech historiography quickly and successfully since the beginning of the 1960s. The knowledge about the age at marriage and age at death showed a different tempo of the lifecycle in men and in women. The family reconstitution indicated the forms of marriages and family relationships in the past. The texts in historical demography have systematically treated the key "feminine" topics, particularly in association with the study of natality and nuptiality. ${ }^{14}$

Despite the increasing number of studies and the huge amount of knowledge which they brought, the Czech agrarian historiography did not experience any distinct methodological or thematic shift following the European research trends until the end of the 1990s. Moreover, the first study dealing with rural women appeared in Czech professional periodicals due to foreign authors.

In 1998, Sheilagh Ogilvie and Jeremy Edwards published a text in the journal Historická demografie, which was based on North Bohemian archival sources. ${ }^{15}$ The study about the status of women at the time of the "second serfdom" after the Thirty Years'War followed up the period norms and their real reflection in rural space. The authors mainly paid attention to the status of women in households which were enlisted in population registers, and to the local court rulings concerning the women. Their work with common sources, which were well known to Czech historians, inspired the researchers mainly with regard to the outlined interpretation possibilities. The authors interpreted the status of women as an indicator of social and economic development of the society. They focused on the position of female householders and on the arguments by which it has been conditioned or called into question.

12 From the most recent works Milan Šmerda, Život Ondry Foltýna, slezského rodáka a statečného človèka, Brno 2003.

13 In prestigious collective monographs inspired by the work of Jacques Le Gorf (ed.), L'Homme médiéval, Paris 1994, which presented the image of particular population groups in the Czech lands during the Middle Ages and Early Modern Times, many chapters are targeted specifically at women or men, but the "peasant" or "villager" is in both cases a male: Jaroslav ČchurA, Sedlák, in: Martin Nodl - František Šmahel (edd.), Clověk českého středověku, Praha 2002, s. 436-459; Josef Grulich, Venkovan, in: Václav Bůžek - Pavel Král (edd.), Člověk českého raného novověku, Praha 2007, pp. 166-189.

14 Ludmila Fialová a kol., Dějiny obyvatelstva českých zemí, Praha 1996.

15 Sheilah Ogilvie - Jeremy Edwards, Ženy a „druhé nevolnictvi“ v Čechách na počátku novověku, Historická demografie 22, 1998, pp. 5-49. 
They followed up the way of how the society of that time, represented by reeves and aldermen, formulated their (usually negative) attitudes towards independent female householders.

The first original Czech studies appeared soon thereafter. They paid attention to the methods, which could elucidate the gender relations within lower social classes in the past. It is necessary to remark that even after the year 2000, the authors still felt obliged to explain to the readers what the concept of gender actually means. In 2001, Dana Musilová attempted to introduce the possibilities of gender studies in connection with current social history research. ${ }^{16}$ According to her essay, gender was applied less intensively in historical research than in sociology at the turn of millennia. The same was also true of social history, even though both of these methodological approaches have many common traits and topics, for example the emergence and functioning of gender roles, relationships in family or at work, and membership in social groups.

In the same year, the first thematic treatise on rural women appeared. Its author, Josef Grulich, accentuated the importance of studying this topic in connection with historical demography. ${ }^{17} \mathrm{He}$ tried to summarize several results of previous research on the history of rural family with regard to the lifecycle of rural women in connection with marriage and motherhood, and he also addressed the economic rights of women.

The 2005 collected conference volume, which was dedicated to the development of women's history and gender studies from the perspective of Czech historiography, contained an extensive study by Alice Velková Rural women between the years 1650-1850, dealing with the perspectives of research into this problem area. ${ }^{18}$ The author regarded the history of family as the most important methodological possibility, which corresponded to her own research profile, similarly as it was with Josef Grulich. The tight connection of rural women with family, or with family estate, is of course partly given by the representation of rural women in archival sources. However, the surviving stereotype of a woman - mother - housewife in "traditional“ family also might play a certain role, although this concept was formed by the $19^{\text {th }}$ century burgher ideology and many historians have disproved it as it could not be really fulfilled in most (rural) women.

Alice Velková defined in her study four thematic areas, to which researchers should pay the most part of their attention. It was the study of demographic phenomena and their connection with socio-economic aspects, topics of everyday life, lifestyle, lifecycle

16 Dana Musilová, Možnosti uplatněni gender v sociálni historiografii, Studie k sociálním dějinám 8 , 2001, pp. 45-52.

17 Josef Grulich, Venkovská žena v obdobi raného novověku (16.-18. století), Československá historická ročenka 2001, pp. 223-235.

18 Alice Velková, Venkorské ženy v letech 1650-1850. Perspektivy výzkumu s využitím historické demografie, mikrohistorie, historické antropologie a dějin každodennosti, in: Kateřina Čadková - Milena Lenderová - Jana Stráníková (edd.), Dějiny žen aneb Evropská žena od středověku do 20. stoleti v zajeti historiografie, Pardubice 2006, pp. 125-144. 
and the ideological world of rural women, the relationship of women to property, and the status of women at the periphery of society. From her comments and from the referenced works follow a distinct inequality in the study of individual topics of Czech agrarian historiography and the concentration of "gender history“ on women, particularly those who were exceptional in some way. These facts unfortunately still survive in the contemporary Czech historiography.

Rural history is above all the history of people who left behind them very few written sources. This is partly caused by the persisting illiteracy and lack of time for writing and reading, and partly by the closeness of the rural world, where the people mostly did not need to write any documents, for example letters. The majority of written and pictorial reports on rural people were made by observers who stayed outside the rural society or at its boundary. The first real ego-documents did not appear until the end of the $18^{\text {th }}$ century. The authors of official records, which documented and influenced the everyday life of rural population, were manorial officials or priests. In manorial or parish offices they left many stereotypic and usually very short records, from which the historians with great difficulties reconstruct the life stories of individual people.

These facts naturally affect the possibilities of research, but at the same time it must be said that researchers only rarely regard their study topics from multiple perspectives, and they do not like to abandon the spectrum of sources with which they usually work. In the Czech milieu, no extensive analytic interdisciplinary multi-authored studies are written. The main reason thereof is an insufficient connection between the research of historians, who preferably use written sources, and the ethnological studies, which utilize the material, pictorial as well as folklore sources, whose exact temporal or social scope, however, can rarely be defined.

Since recently, historians show an increased interest in the individuality of rural people and in the social stratification of rural space. The new millennium papers already work with the concept of multi-layered and variable rural society. Fifteen years ago, Alice Velková claimed that a low level of knowledge would concern not only the history of rural women, because „an equally low attention is also paid to rural men“ .19 The situation today is quite different. Thanks to the interest of mainly young researchers we already know relatively much about the life of rural women, whereas their male counterparts remain hidden in the crowd of subjects or „rural folks“.

The aim of the presented paper is to summarize the results of previous research on the role of men and women in early modern and $19^{\text {th }}$ century traditional Czech rural society, and to outline the possibilities of further research. The text is structured thematically for better clarity. It begins with areas which are currently better explored or have a longer historiographic tradition, and continues with those which were not yet given much attention. The paper should not provide a complete bibliographic overview, but

19 A. VelKová, Venkouské ženy, p. 126. 
rather draw attention to writings of key importance, which brought a significant factual and methodological progress to the research on gender aspects in rural history, and point out the topics of future research.

An element which very distinctly reflects and forms the different status of men and women is the period law. Older codes of law and seigniorial standards were already edited and published at the beginning of the $20^{\text {th }}$ century. ${ }^{20}$ The $16^{\text {th }}$ century Koldín's Code, which gradually became the key legal standard for the rural milieu, was recently newly edited. ${ }^{21}$ More recent standards from the time after the end of the $18^{\text {th }}$ century are easily accessible in period collections or on the internet servers. Researchers thus have a good starting position in this regard.

The legal aspects of agrarian history were mapped out relatively well already before 1989. The standards which formed the status of the „peasant estate“ as a whole were already studied by Kamil Krofta at the time of the First Czechoslovak Republic (1918-1938). ${ }^{22}$ The family and property law of rural people was analysed in detail in the 1960s. A synthetic work by Jiři Klabouch about marriage and family in the past brought a great deal of knowledge about legal standards which were applied for example in contracts of marriage or in other aspects of family life. ${ }^{23}$ The so far unsurpassed monograph about the immovable property of Bohemian subjects by Jiří Procházka brought many examples of the $16^{\text {th }}$ and $17^{\text {th }}$ century legal practices and paid attention to hereditary rights of men and women, property of married couples or children from various marriages. ${ }^{24} \mathrm{It}$ provided a very good information and methodological basis for further research concerning the relationships of both rural men and rural women to their property.

The inheritance law and the legal situation in subject estates became the focal point of historians in the 1990s again. However, these topics were not studied by legal historians but by historical demographers in connection with their research on family and social structures. Besides the texts dedicated to the development of legal standards ${ }^{25}$ we also know some very extensive works on the effects of these standards in particular

20 Josef Kalouse (ed.), Řády selské a instrukce hospodářské 1781-1850, Archiv český 25, Praha 1910;

Václav Č́ RnÝ, Hospodárské instrukce. Přehled zemédèlských dějin v době patrimonijního velkostatku $v$ XV.-XIX. století, Praha 1930.

21 Josef Jirečex (ed.), M. Pavel Kristián z Koldina, Práva mèstská království českého a markrabství moravského spolu s krátkou jich sumou, Praha 1876; Karel Malý a kol. (edd.), Práva méstská Království českébo, Praha 2013.

22 K. Krofta, Déjiny.

Jiří KLABouch, Manželstvi a rodina v minulosti, Praha 1962.

Vladimír Procházka, Česká poddanská nemovitost v pozemkových knihách 16. a 17. století, Praha 1963.

25 Eduard Maur, Das bäuerliche Erbrecht und die Erbschaftspraxis in Böhmen in 16.- 18. Jahrhundert, Historická demografie 20,1996, pp. 93-101. Alice VELKová, Staatlichen Eingreifen in die Beziebungen zwischen Gutsherrschaft und der Untertanen. Zu Erbrecht und ländischer Familienstructur in 
regions, which will be mentioned below in the text. In this context also emerged the earliest works about the status of widows - the first independent women in rural milieu. The (civilian) legal aspects of rural life in the past centuries are currently not systematically studied; this topic is presented with the help of older publications in monographs with different thematic scope.

A great deal of knowledge, which enables more extensive temporal and spatial comparisons, was acquired in the field of historical demography and family history. The family reconstitution became well-established in the 1960s and together with other constantly improved methods it yielded knowledge about various aspects of population composition, natality, nuptiality and mortality. The results of quantitative analyses clarified the usual lifecycle of men and women and they also regularly provide starting points for further research. However, in the Czech milieu we encounter conceptual problems with the technically and personally demanding comparative research, which could indeed evaluate representative population samples using the unified excerptions. An advantage of recent years is the progressive digitisation and the on-line access to archival records, although their method and tempo are different, depending on the attitude of particular State Regional Archives. Nevertheless, for the time being there can be no talk of the creation of any complex databases.

The weakness of demographic research naturally consists in the vast generalisation and reduction of real persons to ,items“ and „numbers“. However, the quantification of population data offers an explanation or at least description of many complicated problems of human behaviour. For example, the problem of nuptiality and fertility, which was mapped out very thoroughly during the 1990s already, proved a different development in urban and rural space. Minor attention was paid to mortality, above all to the interpretation of differences in the mortality of men and women in various historical periods. A more detailed study of the increased death risk in persons of given sex and age and study of the causes of death might help to elucidate the lifestyle and the demands placed on men and women in traditional society. The sex division of the examined population samples is used with migration research. ${ }^{26}$

An interesting interpretational project, which is based on the methods of historical demography, is the currently running research testing of the "grandmother hypothesis“. ${ }^{27}$ According to this original biological theory, the presence of a grandmother (or some

Westböhmen an der Wende vom 18. zum 19. Jahrbundert, in: Markus Cerman - Robert Luft (edd.), Untertanen, Herrschaft und Staat in Böhmen und im „Alten Reich“, München 2005, pp. 154-175.

26 Josef Grulich, Migrace mèstskébo a vesnického obyvatelstva. Farnost České Budějovice 1750-1824, České Budějovice 2013 (Monografia historica 10).

27 Jan Horskŕ - Jan Havlíčeк, Testováni „hypotézy babiček“: historicko-demografická perspektiva, Historická demografie 41, 2017, pp. 189-211; Alice VelkovÁ, Přitomnost babiček v předindustriálních rodinách a jejich možný vliv na plodnost dcer, Historická demografie 41, 2017, pp. 213-234. 
other woman in her place) gives the newborn members of younger generation a higher chance to survive and enables the mother an earlier conception of an another child.

Motherhood, as a crucial topic in women's history and at the same time as a key element of demographic analyses, rightly became the focal point of research. Nevertheless, it virtually completely excludes those who did not (no longer) participate in the reproduction process for whatever reason. The major part of rural men and women did not marry at all, were childless, or were widowed very soon. Their life stories represent a very interesting research topic, because they hold up a mirror to the preferred gender role characterised by parenthood. The questions of where and with whom the partnerless people lived, how they earned their living and who was a possible support to them, are very important for understanding the rural world. The way how this society perceived the unmarried men and women, how it approached unconsummated marriages and bereaved parents of small children, reveals many differences in the status of men and women and in construction of their gender identity.

The problem of unmarried adults was treated in connection with studies on the status of single mothers and illegitimate children. However, the requirements of the religious and legal discourse ${ }^{28}$ did not always correspond to the perception of extramarital sexuality in the rural space. ${ }^{29}$ The testimonies of persons accused of lechery and adultery were studied by Jaroslav Dibelka who regarded them strictly from the perspective of gender. ${ }^{30}$ Other investigations were unfortunately devalued by an excessive effort to popularise the topic. To this day, historians were only interested in „undesirable“ sexual conduct, which in the early modern times was put to trial and, consequently, recorded in writing. Nothing is known about this problem in the $19^{\text {th }}$ century, when the cohabitation of unmarried partners was no longer sanctioned. The perception of human body and corporality through the prism of mentality of rural people remained completely neglected.

Sexual offences usually are part of broadly conceived works dealing with the history of ,crime and punishment“, which are often published in a form accessible to non-professional audience. ${ }^{31}$ Attention was also paid to typical "masculine“ or "feminine“ forms of criminality and their perception by the society of that time. For example, we can

28 Daniela Tin ková, Hřich, zločin, šilenství v čase odkouzlováni svèta, Praha 2004, pp. 310-356; IDEM, Tèlo, věda, stát. Zrozeni porodnice v osvícenské Evropè, Praha 2010.

29 Alice Velková, Nemanželské děti ve venkovské společnosti na přelomu 18. a 19. století, in: Tomáš Jiránek - Jiří Kubeš (edd.), Dítě a dětství např́ič staletími (= Scientific Papers of the University of Pardubice, Series C, Supplement 5), Pardubice 2002, pp. 205-227.

30 Jaroslav Diвеlкa, Obrané strategie mužů a žen obviněných ze smilstva a cizoložství. Panství Třeboň na prelomu 17. a 18. stoleti, České Budějovice 2012.

31 We can mention numerous works by Jindřich Francek, for example Jindřich FranceK, Zločin a trest v českých dẽjinách, Praha 2000; IDEM, Zločin a sex v českých dějinách. Manželské spory a sexuální kriminalita v raném novověku, Praha 2000. 
mention the figures of bandits and their transformation into folk heroes who became the subject matter of ethnological research. ${ }^{32}$ Women were usually blamed for the tragic ending of unsuccessful partnerships which resulted in killing of the unwanted newborn. ${ }^{33} \mathrm{~A}$ systematic analysis was made with cases of women who murdered their own husbands and elder children. ${ }^{34}$ The escape from an oppressive relationship of course did not necessarily have the form of a criminal act. The petition for dissolution of marriage, which was usually justified in the inability to fulfil the general expectations placed on a man or a woman, also represented a breakage of norms with the risk of subsequent condemnation..$^{35}$

The popularity of historical anthropological studies in the style of Richard van Dülmen, which turned the attention of many Czech researchers to the problem of criminal issues, can cause an overgeneralization of accidentally preserved sources and neglect of "ordinary" people, who have never brushed with the law. The studies about rural space from the past two decades therefore implemented the method of micro-historically conceived family history, which is mastered by individual researchers better than the demanding quantitative analysis and keeps the focus on individuals. On the example of selected localities they connect the reconstitution of family and social structures with the research on tenure and inheritance of rural estates.

In this area we can observe, particularly in the 1990s, a distinct inspiration by the works of historians associated with Michael Mitterauer and the „Göttingen school“, above all with Jürgen Schlumböhm, Hans Medick, and Peter Kriedte. Of key importance was an international project titled Soziale Strukturen in Böbmen, which was realised in cooperation of Czech and Austrian experts. However, in the scope of this project also some wider international contacts were established. ${ }^{36}$ The dominant influence of

32 Jindřich Francek, Dějiny loupežnictva: Zloději, loupežníci, lupiči, pytláci a žhárí v českých dějinách, Praha 2002; Adam Vot ruba, Pravda u zbojnika. Zbojnictví a loupežnictví ve střední Evropè, Praha 2010.

33 Daniela Tinková, Ilegitimita a „nová ekonomie života"v osvicenské Habsburské monarchii. Problém svobodných matek a nemanželských dèti mezi sociální kontrolou a sociální péči na prahu osvicenské společnosti, Historická demografie 27, 2003, pp. 133-172; Alice Velková, Nemanželské dèti ve venkovské společnosti na prélomu 18. a 19. století, in: Tomáš Jiránek - Jiří Kubeš (edd.), Dítě a dětství napříč staletími (= Scientific Papers of the University of Pardubice, Series C, Supplement 5), Pardubice 2002, pp. 205-227.

34 Alice Velková, Schuld und Strafe. Von Frauen begangenen Morde in den böhmischen Ländern in der zweiten Hälfte des 19. Jahrhunderts, München 2012.

35 The problem of marriage disputes and divorces in relation to the rural space was only addressed in the work by Zuzana Pavel ková Čevelová, Každodennost manželstvi 19. stoleti v Čechách pobledem soudnich akt a príruček pro katolické knèze, Pardubice 2015.

36 Markus Cerman - Hermann Zeit lhofer (edd.), Soziale Strukturen in Böhmen. Ein regionaler Vergleich von Wirtschaft und Gesellschaft in Gutsherrschaften, 16.-19. Jahrhundert, Wien-München 2002. 
German-written historiography on the working methods of Czech researchers partly receded into the background in the past decade, in connection with the rise of a younger Anglophone generation.

With some delay after the completion of the above-mentioned project, which was intended to clarify the transformations in the composition of the Bohemian rural space from the Thirty Years'War until the mid $-19^{\text {th }}$ century, a monographic series was published, including dissertations by the authors who connected the beginning of their scholarly career with this project. ${ }^{37}$ In their publishing outputs we can more or less often find rural women in the role of brides, estate heiresses or widowed housewives. Dana $\check{S}_{\text {tefanová }}{ }^{38}$ and Alice Velková ${ }^{39}$ elaborated their knowledge of widowed rural female householders in several partial journal studies, where they mainly paid attention to the possibilities which were offered to farmwives and cottagers after the death of their husbands.

The economic activity of women in the rural space is so far insufficiently explored (and in the case of some researchers also undervalued). Ethnological studies give evidence of gender-based division of work roles and, consequently, of a partial separation of financial incomes in traditional agrarian economy. While the sale of corn and of large heads of livestock was the husbandman's business, farmwife was responsible for selling the surplus products in the form of eggs, milk, poultry or fruits. From recent literature

37 Josef Grulich, Populačni vývoj a životni cyklus venkovského obyvatelstva na jihu Čech v 16. až 18. stoleti, České Budějovice 2008; Alice Velková, Krutá vrchnost, ubozi poddani? Promèny venkovské rodiny a společnosti v 18. a proni polovině 19. stoleti na př́kladu západočeskébo panstvi Š́táblavy, Praha 2009; Dana ŠTEFanová, Erbschaftspraxis, Besitztransfer und Handlungsspielräume von Untertanen in der Gutsherrschaft. Die Herrschaft Frýdlant in Nordböhmen 1558-1750, Wien-München 2009; Hermann ZeItLHOFER, Besitzwechsel und sozialer Wandel. Lebenslaufe und sozioökonomische Entwicklungen im südlichen Böhmerwald, 1640-1840, Wien-Köln-Weimar 2014; Markéta PrAŽÁKová Seligová, Život poddaných v 18. stoleti: osud, nebo volba?: K demografickým, hospodářským, sociálním a rodinným aspektưm života venkovských poddaných na panství Horni Police, Praha 2015.

38 Dana Štefanová, Zur Stellung von Witwen in ländlichen Gesellschaften den Frühen Neuzeit zwischen 1558 und 1750, in: Václav Bůžek - Dana Štefanová (edd.), Menschen - Handlungen - Strukturen. Historisch-anthropologische Zugangsweisen in den Geschichtswissenschaften, Ceské Budějovice 2001 (= Opera historica 11), pp. 197-217; IdEm, Vdovy v raném novovéku. Studie k právnimu postaveni a jednáni „viditelných“ ¿̌en na prúkladu praxe panství Frýdlant v severních Čechách mezi léta 1550-1750, SPFFBU, C 51, 2002, pp. 49-69.

39 Alice Velková, Sebevédomé, nebo zoufalé? Vdovy hospodařici na venkovských usedlostech v prvni polovině 19. století, in: Milan Vojáček (ed.), Reflexe a sebereflexe ženy v české národní elitě 2. poloviny 19. století. Sborník prŕíspěvků z konference uspořádané ve dnech 23.-24. listopadu 2006 Národním archivem ve spolupráci s Archivem hlavního města Prahy, Praha 2007, pp. 321-340; IDEM, Staré ženy ve venkorské společnosti na prelomu 18. a 19. století, in: Zdeněk Hojda - Marta Ottlová - Roman Prahl (edd.), Vetché stáríi, nebo zralý věk moudrosti? Sborník příspěvků z 28. ročníku sympozia k problematice 19. století. Plzeň, 28. února-1. března 2008, Praha 2009, pp. 204-226. 
we know an information by Daniel Drápela about fruit trade in the surroundings of Brno, which was organised by women..$^{40}$

Czech researchers reacted to the discussion about proto-industrialisation, but they in fact did not introduce any research results concerning the real work opportunities and earnings of people who participated in household production. It is evident that mainly the textile production, beginning from spinning and ending with production of small garment accessories, was to a great extent female business and it might also have been a way to at least partial independence. Completely out of the scope of analyses are the households of later rural metalworkers and part-time farmers in industrial areas, who were employed outside their homes and the family farms were managed above all by their wives. The wives of seasonal migrant workers had to cover the usual expenses during a longer period of their partners' absence. In Czech historiography, the sources of these „female“ incomes were not yet studied, although the western science pays a great deal of attention to this topic, particularly in the context of subsistence of single-parent families. ${ }^{41}$

In accordance with the period discourse, Czech historians ascribe the wage-earning activities to men, whereas women allegedly played the role of housewives who should properly administer the resources secured by the husband or produced at the farm. Nevertheless, this distinct gender-based concept of a polarised functioning of rural households is based on two assumptions, which were not always fulfilled: namely that the family had an own agricultural background and that it was led by a complete couple.

In the course of the $19^{\text {th }}$ century we can observe an increasing number of couples with children, who did not own agricultural land and were dependent on wage labour. Besides various forms of day-labour and auxiliary works, whose execution was mainly based on physical dispositions of individual workers, be it women, men or children, in the rural space we can also identify several forms of gender-specific extra incomes. To these activities belonged specialised production: the more or less qualified men carried out various crafts, whereas women were occupied for example with sewing or embroidery of „better" clothes. Little is known about the creation of true „folk art", but we know that this activity was not generally widespread. It represented a "profession“ of gifted or skilled individuals (both men and women) who lived above all in larger rural centres or small towns. ${ }^{42}$

40 Daniel Drápela, Venkovský obchod Moravy a Slezska: Socio-ekonomické sondy, Brno 2014.

41 Most recently also with relevant literature Beatrice MoRING - Richard WALL, Widows in European Economy and Society, 1600-1900, Woodbridge 2017.

42 In summarizing overview with further literature, Lubomír Tyllner (ed.), Velké dèjiny zemí Koruny české. Lidová kultura, Praha-Litomyšl 2014, especially the pp. 174-226, 662-703. 
A typical female occupation, which also was the first „certificated“ profession open to women, was the practice of midwives, to whom the present-day Czech historiography pays a great attention. Of topical interest is a project dealing with the so-called birth diaries, from which we can reconstruct the education, working conditions, customer ranges and earnings of individual midwives. ${ }^{43}$ Natural healing and home care were traditionally ascribed to women, and midwifery was the first, but not the only, formalised „professional“ way of their self-realisation. Another means of subsistence, which spread around the Bohemian and Moravian rural space in the course of the $19^{\text {th }}$ century, was the placing of urban „orphans“ in families who got small remuneration for caring for a parentless child. This money might have been a welcome additional source of livelihood. However, this form of profitable activity of married rural women, evidently considerably widespread in several regions, was not yet given adequate attention.

The access of women to economic resources and wage-earning activities naturally became a fundamental problem when the male „bread-winner“, be it the husband or the father, was absent or passed away. The study of the problem of widows was already mentioned above, and in the past few years we registered an increased number of papers dedicated to orphans or, more generally, to incomplete families. ${ }^{44}$ The situation in orphaned families directly induced an at least temporary shift in gender roles of the widowed parents, who had to substitute their deceased partners. However, this topic is by far not sufficiently explored, particularly as regards the living conditions of widowed men.

The perception of motherhood, fatherhood, fulfilment of parental or grandparental role and upbringing of children in the family are topics of great importance. In rural space, however, they are mostly neglected. As regards the women-mothers, we can base ourselves analogically on studies dedicated to upper social classes; the attitudes of rural fathers, however, stand completely apart from the research area of Czech historians. Also the childhood, adolescence and upbringing of sons and daughters in the rural space are very insufficiently explored.

The research on intimacy of interpersonal relationships in the case of lower social classes is of course always very problematic and limited by the existing source materials. A suitable solution for later periods might be a comparison with oral history, ${ }^{45}$

43 Vladan Hanulík (ed.), Porodila štastně děvče... Porodni deníky čtyř porodnich babiček z 19. století, Pardubice 2017; Hana Stoklasová (ed.), Porodní bába? Asistentka? Porodni deníky z let 1898-1954, Pardubice 2018.

44 Markéta SкоŘepová, Ovdověni a osiřeni ve venkovské společnosti. Panství Nový Rychnov (1785-1855), České Budějovice 2016 (Monographia historica XVI); Věra SLovákovÁ, Životní poméry dívek a mladých žen ve vsi Křrenovice v 18. století, Historická demografie 42, 2018, pp. 211-237.

45 The oral history research in the Czech milieu is rather focused on historical events during the turbulent $20^{\text {th }}$ century. The ,interviews with personal observers”, which were made relatively 
for earlier periods it might be a systematic analysis of folklore or fictional literature. In present-day Czech historiography, the citations from rarely preserved correspondence of rural people and the extracts from folk songs are unfortunately preferably used as picturesque illustrations rather than as sources of profound analyses. ${ }^{46}$ Relatively neglected still remain the rural stories and novels, which were very popular in the second half of the $19^{\text {th }}$ century and in the early $20^{\text {th }}$ century. Despite their artistic ambitions they can provide a valuable insight into the everyday life of rural people. Many authors of rural novels, especially the male authors, pursued in their writings certain political goals and conceived these literary works rather as social novels, which should draw attention to society-wide problems rooted in the rural space. ${ }^{47}$

The works written by women were targeted at women again, without any of the above-mentioned „serious“ goals. However, their value as a source for historical research increases thanks to the good observant eye and the ethnological interests of their female authors, who were not only engaged in literature, but occupied themselves seriously also with folklore and vernacular culture. ${ }^{48}$ Moreover, certain degree of „female solidarity“ helped these authors to better portray the „feminine“ aspects of family and interpersonal relationships, which cannot be identified in the official documents written by male officials and communal representatives.

The inner personal feelings and descriptions of everyday life moments are only rarely found in the records made by folk chroniclers and the members of rural society, who felt the urge to record their thoughts in writing. ${ }^{49}$ These men (female authors did not yet appear) wrote for their close relatives and friends and for their descendants, so that we must take into consideration certain degree of self-censorship and self-stylisation and omittance of topics which were regarded as trivial or unworthy of recording. However, it could be possible and suitable to search here for the reflections of the period discourse, also with regard to the expected gender-specific behaviour.

systematically before 1989 , as well as the more recent ethnological research, represent so far an unused potential for the study of gender roles and individual experiences of men and women.

46 An anthology of these sources was published by Václav Frolec, Prostá krása. Deset kapitol o lidové kultuře v Čechách a na Moravě, Praha 1984.

47 Eduard KubŮ - Jiří ŠoušA - Aleš ZÁřıckÝ (edd.), Český a německý sedlák v zrcadle krásné literatury 1848-1948: Diskurz mezi historii a literárni védou na téma selského a hraničářskébo románu, Praha 2014.

48 As an example we can name the "great” and recognised female writers like Božena Němcová or Teréza Nováková, as well as female authors of minor artistic importance, such as Vlasta Pittnerová.

49 Folk chronicles and scripturalistic records are mostly published in the form of editorial series, most recently Alžběta Kulíšnová (ed.), Zápisky sedláka Josefa Dlaska. Měl jsem nestálé štěstí, Turnov 2015. 
The differences between „feminine“ and „masculine“ were also apparent from the point of view of the appropriated space of rural society members. Particularly in the case of unmarried young people, the meeting places of both sexes usually were symbolically separated, be it the shared space of the church, tavern or the communal entertainment events. Certain places were associated with collective works and gender-specific activities, so that they also functioned as a space for socialisation of individuals. However, the gendered space in traditional village was not yet sufficiently explored. Attention is only paid to crossing of the geographic borders in immediate neighbourhood.

The migration research has repeatedly proved that the „world“ of rural people was far wider than usually thought, and this applies to both men and women. ${ }^{50}$ Continuous migrations may have resulted in abandonment of one's own social class, whether by social advancement or, vice versa, by the fall from the social ladder. The range of migrations, their motivations and strategies of survival „on the road“ were of course very individual and the possibility of their reconstruction depends on the relatively rarely preserved sources. From recent years we know published life stories of early modern women who left their familiar environment, but their fates were only revealed due to the fact that they brushed with the law. ${ }^{51}$ Even more complicated is to follow up the temporary mobility, which naturally brought a widening of horizons to its direct participants and their neighbourhood. In the case of men it was associated with military service, apprenticeship and also with studies. Both men and women had the possibility to improve their work skills and earn money as servants.

A specific type of migrations were religious pilgrimages. The pilgrims often revisited favourite places in their close neighbourhood, but sometimes they were also able to travel over very large distances. During the $19^{\text {th }}$ century at the latest, the participation in religious pilgrimages as well as in other ecclesiastical rituals became predominantly a female activity. The question of religiosity of rural space is a popular topic, whose study also comprises gender aspects, although usually only in the form of reflections or statements rather than profound analyses. Better explored, as regards the gender aspects, is the form of Marian cult or worship of favourite saints. ${ }^{52}$ The role of women in the early

50 Barbora MlynaŘínová, Geografický horizont prostého člověka v Čechách v letech 1740-1830, I-II., Praha 2001.

51 Jaroslav Dibelka, Př́běh Johany Peřkové. Každodenní život tulačky a zlodějky v první polovinè 18. století, in: Václav Bůžek - Jaroslav Dibelka (edd.), Člověk a sociální skupina ve společnosti raného novověku, České Budějovice 2007 (= Opera historica 12), pp. 315-332; Josef Grulich, Migrační strategie: Mèsto, predmèstí a vesnice na panstvi České Budějovice ve drubé polovinè 18. století, České Budějovice 2018 (= Monographia historica 17).

52 Markéta Holubová - Marcela Suchomelová, Salve Regina-Mariánská úcta ve středních Čechách, Praha 2015; Jakub IvÁNeK, Svébytné konstrukce identity mužských svètcích v českých barokních pisnich, in: Radmila Švaříčková Slabáková - Jitka Kohoutová - Radmila Pavlíčková - Jiří Hutečka a kol., 
modern religious non-conformism, or in emancipation of the reformed belief during the Toleration Period, was only broadly outlined.$^{53}$ Different attitudes of men and women to the official and predominant Catholicism in the relatively secularised $19^{\text {th }}$ century are only rarely analysed. Research was made on the influence of the Catholic ideology on the "upbringing“" of both sexes. ${ }^{54}$

The folk religiousness and its non-conform displays are tightly connected with the issues of education, reading or, more generally, folk culture. ${ }^{55}$ The reception of early modern semi-vernacular book production from the perspective of gender is treated in a commented edition. ${ }^{56}$ An outstanding source of research into women's history are the broadside ballads, which are currently being analysed in detail. ${ }^{57}$ The attention should be extended to the problem of gender. Of key importance could be the presentation of steady stereotypes of masculinity/femininity in broadside ballads or popular books and the so-called calendars. A related and equally important topic could be the reader's reception of these prints, which often represented the only contact of rural people with written literature.

The development of printed media in the course of the $19^{\text {th }}$ century also signified the penetration of new ideas into the rural space. A relatively new topic is the reflection of national emancipation movement and various political streams from the perspective of agrarian history. However, the problem of gender representations in agrarian policy and their orientation towards rural voters was not yet addressed. The advertising ,rural novels" from the turn between the $19^{\text {th }}$ and $20^{\text {th }}$ centuries still must be analysed from the point of view of presented images of femininity and masculinity. ${ }^{58}$

Konstrukce maskulinní identity v minulosti a současnosti. Koncepty, metody, perspektivy, Praha 2012, pp. 126-141.

53 Zdeněk R. NEšpor, Náboženství na prahu nové doby. Česká lidová zbožnost 18. a 19. století, Ústí nad Labem 2006.

54 Zuzana Č́evelová, Gender, víra a manželstvi v „dloubém“ 19. století: Možnosti interpretace katolických normativních pramenư, Pardubice 2012; partly also Markéta Sког̌EPová, Čas křtu a výbér jména novorozence ve venkovské společnosti 19. století, Český lid 105, 2018, pp. 199-218.

55 The overlap of social history and culture in rural space was treated from a micro-historical perspective by Roman Doušen, Sebranice a jejich rychtár Ondřej Kanýz (1694-1761). Vesnická komunita a jeji kultura v proni polovinè 18. století, Brno 2009.

56 Jana Ratajová - Lucie Storchová (edd.), Žádná ženská člověk není. Polarizace genderũ v českojazyčné literatuře drubé poloviny 18. století, Praha 2011.

57 Markéta Holubová (ed.), Obrazy ženy v kramářské produkci, Praha 2008.

58 The presentation of rurality from national perspectives in a mirror of fictional literature from the turn between the $19^{\text {th }}$ and $20^{\text {th }}$ centuries was treated in the successful monograph E. Kubu - J. Souša - A. Zářický (edd.), Český a némecký sedlák. However, the discourse of Bohemian and German peasants was analysed here with no regard to gender aspects, which also remained neglected in the description of female characters in novels under analysis. 
Rural history represents a very free concept, which comprises many research topics and methodological approaches. They are related to a very broad social group, which is defined by the inhabited space and specific way of life, where the major part of population in the past identified themselves or were identified with these characteristics. The spectrum of preserved sources helps to solve only a few of the existing problems, but in other cases it causes limitations. Limited is the analysis of questions brought up by modern historiographic research, which endeavours to find either the general discourse or the individual formed by this discourse. The analysis of gender aspects in everyday Czech rural life and culture also falls within this range.

The above sections of the article tried to summarize the existing results of a reflection of the concept of gender in the Czech agrarian historiography. We can probably speak about a general consensus of Czech historians about the necessity of gender studies, or at least of the analysis of gender aspects in the research on „traditional“ topics. However, the factual implementation of gender as an analytical tool in real research practice can not be taken for granted. ${ }^{59}$

Women's history in Czech milieu won a strong response both from experts and from non-professional community. The research focused on rural space followed up the extensive studies of demographic development and social structures. Similarly to the other areas of historiographic research, the amount of knowledge about rural women and their daily life quickly surpassed the amount of relevant knowledge about rural men. Many present researchers in the field of social history of Czech rural space try to draw attention to the diversity among members of both sexes and to differences in their status and experienced situations.

Nevertheless, the representations of masculine and feminine identities in rural space still remain neglected, although there is no doubt that the traditional society was distinctly polarised into masculine and feminine. ${ }^{60}$ No research was made about the normative discourses in rural space, which differed from the ideal standards of upper classes that are relatively well explored. The most important discourse in rural reality probably was the discourse of a good husbandman and good housewife, on whom the society probably placed somewhat different demands than in the urban milieu. However, the gender determination of prescribed or generally accepted standards and a different assessment of their violation by men and women are mostly only noticed rather than really analysed.

Rural history currently does not count among the most popular and well-staffed branches of historiographic research in the Czech Republic. It is characterised by a distinct inequality in exploration of various historical periods and in treatment of

59 In the sense of the work by Joan W. Scotт, Gender. A useful category of historical analysis, The American historical review 91, 1986, no. 5, pp. 1053-1075.

60 Arnold van Gennep, Les rites de passage: étude systématique des rites, Paris 1909. 
various topics. Some of these thematic areas are relatively popular, others remain almost completely neglected. The specifics of preserved sources and usually also their protracted excerption lead to a sort of conservativism, which is in principle open towards new methodological and interpretational impulses, but hesitates to implement them in practice.

Nevertheless, it seems that the concepts of gender history, which were introduced for the first time around 2000, put down deep roots in Czech historiography. We can hopefully expect that an essay about gender history and rural history, which possibly occurs some years later, will be much more comprehensive than this text and its conclusions will be far more optimistic. 
Markéta Skořepová

\section{The Concept of Gender in the Czech Rural History and Historiography (Abstract)}

The article summarizes the existing reflection of the concept of gender in the Czech agrarian historiography. Despite a general consensus about the necessity of the gender history, the factual implementation of gender as an analytical tool is still uncommon. The first studies dealing with rural women appeared in the 1990s. The amount of knowledge about rural women quickly surpassed that about rural men. The most progressive research area in the field of gender history is the history of the rural family, also dealing with the problems of life cycle and land tenure.

KEYWORDS:

gender history; rural history; historiography 